\section{Overview of Some Learning Methods for Early Childhood}

\author{
Vera Sri Wahyuni ${ }^{1}$, Grida Saktian Laksito ${ }^{2 *}$ \\ ${ }^{1,2}$ Research Collaborations Community, Bandung, Indonesia \\ *Corresponding author email: gridasaktianlaksito@gmail.com
}

\begin{abstract}
Choosing a learning method in early childhood education is a method used by educators in carrying out learning activities for children to achieve certain competencies optimally. The purpose of this review of several learning methods in early childhood education is to obtain information about the growth and development that has been achieved by him during his education in learning in early childhood education. There are several lessons in early childhood education, and each method has its advantages and disadvantages. Based on the results of the discussion, it is known that each learning method in early childhood education has advantages and disadvantages. Therefore, educators in early childhood must be able to choose an appropriate method according to the goals, situations and conditions of their students.
\end{abstract}

Keywords: Early childhood, educators, learning methods, certain competencies, optimally.

\section{Introduction}

Education is a citizen's right, and education at an early age is the right of citizens to develop their potential from an early age. Based on various studies that early age is the best foundation in developing their lives in the future. In addition, education at an early age can optimize children's basic abilities in receiving the educational process at later ages (Danby et al., 2018).

Based on Law no. 20 of 2003 concerning the Indonesian National Education System (Sisdiknas), the existence of early childhood education is legally recognized. It is contained in section seven, article 28 paragraphs 1-6, where early childhood education is directed at pre-school education, namely children aged 0-6 years. In the elaboration of understanding, Law no. 20 of 2003 concerning National Education System states that: "Early childhood education is a coaching effort aimed at children from birth to the age of six years which is carried out through the provision of educational stimuli to help growth, and physical and spiritual development so that children have readiness to enter education. further" (Ministry of Education and Culture, 2007; Directorate General of Out-of-school Education and Youth, 2002).

Therefore, mastery of early childhood learning methods is one of the competencies that every teacher must have, so that the learning process can encourage children's development, both intellectual, physical and emotional development. Mastering learning methods, besides of course other abilities, a teacher can manage the learning process in accordance with the objectives to be achieved, namely the abilities that are expected to be possessed by children (Heirdsfield et al., 2007).

Based on the description above, the authors examine various learning methods that are suitable for early childhood education. These methods are then analyzed both their strengths and weaknesses, so that it can be obtained which methods are suitable for early childhood education.

\section{Literature Review}

\subsection{The Goals and Functions of Early Childhood Education}

According to Anderson et al. (2003), in general, early childhood education is intended to facilitate optimal and comprehensive growth and development of children in accordance with the norms and values of life adopted. Through preschool education, children are expected to be able to develop all their potential, including religious, intellectual, social, emotional, and physical. Also has the basics of aqidah that must be in accordance with the teachings of the religion he adheres to, has the expected behavior habits. In addition, children are expected to master a number of basic knowledge and skills according to their needs and level of positive development. 
In accordance with the formulation of the objectives above, it can be stated that in general there are five main functions of preschool education, namely: a) Potential development function; b) The function of planting the basics of aqidah and faith; c) The function of the formation and habituation of the expected behavior; d) The function of developing the necessary basic knowledge and skills; and e) The function of developing a positive learning motivation and attitude (Triputra, 2020; Rahayu and Munadi, 2019).

The five functions of preschool education are actually difficult to separate from each other because all of them are intertwined and integrated in their realization. However, for the sake of explanation, the five functions of preschool education need to be stated explicitly so that preschool educators or teachers do not forget or ignore any of them.

It is assumed that every baby born into the world is equipped with a number of potentials needed to live his life. Behind the helplessness of newborn human babies, lies a number of potentials for life that are far richer than those of other creatures. He has the potential to be religious, think, be creative, feel, communicate with other people and other potentials. Developing the potential of these children is the obligation of educators, parents and teachers.

\subsection{Characteristics of Learning for Early Childhood}

Referring to Heckman (2012), children have different characteristics from adults in their behavior. Thus, in terms of learning, children also have characteristics that are not the same as adults. Characteristics of how children learn is a phenomenon that must be understood and used as a reference in planning and implementing learning for early childhood. The characteristics of children's learning methods are: a) Children learn through play; b) Children learn by building their knowledge; c) Children learn naturally; and d) Children learn best if what they learn considers all aspects of development, is meaningful, interesting, and functional.

Learning activities in early childhood are basically the development of a concrete curriculum in the form of a set of plans that contain a number of learning experiences through play that are given to early childhood based on the potential and developmental tasks that must be mastered in order to achieve the competencies that must be possessed by children.

Based on the opinion above, it can be stated that learning for early childhood has the following characteristics:

1) Learn, play and sing

Learning for early childhood uses the principles of learning, playing, and singing. Learning for early childhood is realized in such a way that it can make children active, happy, free to choose. Children learn through interaction with play tools and equipment as well as people. Children learn by playing in a pleasant atmosphere. Children's learning outcomes will be better if learning activities are carried out with their peers. In learning, children use all of their senses (Heckman, 2012; Heckman, 2011).

2) Development-oriented learning

Development-oriented learning refers to three important things, namely: 1) oriented to the right age, 2) oriented to the right individual, and 3) oriented to the socio-cultural context. Development-oriented learning must be in accordance with the child's age level, meaning that learning must be of interest, the abilities are expected to be achieved, and the learning activities are challenging for children at that age. Humans are individual creatures. Individual differences must also be taken into account by teachers in designing, implementing, evaluating activities, interacting, and meeting children's expectations. In addition to being oriented to the right age and individual, developmental oriented learning must take into account the sociocultural context of the child. To be able to develop meaningful learning programs, teachers should see children in the context of family, community, and cultural factors that surround them (Heckman, 2012).

\section{Early Childhood Learning Method}

Referring to Ecker \& Skelly (2010), early childhood learning methods are methods or techniques used to achieve learning objectives. If the learning model is a general approach in a learning process and usually in a learning process using one model, while the method is a technical step and can use more than one method adapted to the learning model used and the needs of children when learning takes place.

The use of appropriate teaching methods and in accordance with the child's character will be able to facilitate the optimal development of various potentials and abilities of children as well as the growth of positive attitudes and behaviors for children. Technically there are several appropriate methods to be applied to early childhood, including: Lecture, Play, Storytelling, Singing, Conversation (dialogue with question and answer), Field trips, Direct practice, Role playing (social-drama), Assignments, Demonstrations, Experiments, Discussions, Problem solving, and Exercises (Suwahono and Mawanti, 2019; ).

\section{Results and Discussion}

There are several advantages and disadvantages of learning methods for early childhood. The following are some of the authors' analysis of several early childhood learning methods. 
Lecture. This method is very commonly used in the learning process, not least in early childhood education. The advantage of the lecture method is that a lot of material can be delivered in the learning process. The drawback is that it is only one-way, so it does not encourage children to be active and creative.

Play Method. Play is a basic principle of early childhood education, so it is natural that playing is one of the methods that teachers must do in early childhood learning. The advantages of this method are: (a) In accordance with the stage of child development that requires a vehicle in developing all aspects of its development, both physical development, cognitive development and emotional development; (b) Can encourage children's interest in learning, by playing children usually do not realize that they are learning something because their main focus is their interest in playing.

The weaknesses of this method are as follows: (a) If this method is carried out without proper preparation, it is possible that the learning objectives are not achieved optimally because the child is too late in the playing process, especially for example the teacher pays less attention to the stages of learning through this method. ; and (b) This method usually requires well-prepared learning strategies and media. Therefore, the availability of playing media is a condition for the application of this method. The media here is not only in the form of goods but can take the form of various types of games that must be mastered by the teacher so that learning goes well. If the teacher does not provide learning media, the learning objectives will be difficult to achieve.

Storytelling Method. The storytelling method is very commonly used in early childhood learning, especially in conveying messages and values to be internalized to children. The advantages of this method are: (a) It can increase children's motivation to learn, because children are very happy with stories; (b) It is very suitable for affective education (values), because this method can convey good values to children through examples in stories so as to encourage children to do good deeds, while avoiding bad deeds described in the teacher's stories; and (c) Does not require a lot of tools and learning media.

The weaknesses include: (a) In this learning, the teacher is usually more dominant, so that the active role of children is slightly limited. Therefore, teachers must be able to collaborate this method with other methods such as question and answer and singing; and (b) Teachers are required to really master good storytelling techniques, so that children are interested in the stories they bring and the message they want to convey will be well received by children.

Sing. The advantages of the singing method include: (a) It can increase children's motivation to learn, children are usually very happy to sing so that learning through the singing method is very popular with children; and (b) It does not require media that is too difficult to obtain, this method can be done without music or with music, it can also be done by viewing images on VCD. The weaknesses include: the singing method, if done without other methods followed, the learning objectives achieved are slightly limited, for example only developing musical intelligence.

Conversation (dialogue with questions and answers). This method contains several advantages, namely: (a) Children are encouraged to be more active in answering and asking questions, so that they can stimulate their thinking abilities; and (b) The teacher can know the progress of each child, because the teacher can directly assess the child's ability to answer or ask questions. So, the teacher can make a diagnosis and plan follow-up. Weaknesses include: Usually only children who are active and have better intelligence are able to answer and ask questions. In this case the teacher must be able to manage learning through the question and answer method properly, so that every student has the opportunity to answer and ask questions.

Method of Tourism. Usually, the field trip method is carried out in one or two activities in one semester. The advantages of this method are: (a) Students can interact directly with their environment, so that the learning process is more meaningful for children. For example, visits to orphanages, markets, banks, and others; and (b) In accordance with the learning approach that brings children closer to the surrounding environment, namely the CTL (Contextual Teaching and Learning) learning approach. The weaknesses are usually: (a) The recreational element is usually more dominant so that the learning process is excluded; (b) Requires a fee, thus burdening the child's parents; and (c) Places for work tours are usually places with less educational value, such as water booms, swimming pools, and others. Rarely do field trips to places that can increase children's social awareness, for example to slums, orphanages and others.

Direct practice. The advantages of the direct practice method are: (a) Learning is more meaningful because children can directly learn and solve problems directly; and (b) This method is very suitable with the constructivism learning model that is being developed in current learning, which is to stimulate children to think in solving problems. The disadvantages are: (a) Sometimes it requires quite a large cost, especially in direct practice of certain tools; and (b) Without good guidance, usually there are children who have difficulty and do not get proper guidance from the teacher.

Role playing (social-drama). The advantages are: (a) Children can appreciate the roles they play, so that children can take good and bad values from these roles; and (b) Encouraging children's learning motivation, because role playing is a learning method that is more open to children's improvisations so as to encourage children's creativity. The weaknesses are: (a) It takes a lot of time, because the child will not immediately understand the role he will play; and (b) Requires the patience and perseverance of the teacher in guiding children to do the role playing method.

Assignment. The advantages are: (a) Using the assignment method, especially assignments at home, children are more motivated to study at home; and (b) With assignments at home, children's activities will be more positive. The disadvantage is that sometimes if the task is too much it will burden the child and reduce playing time. 
Demonstration. The advantage of this method is that children see and experience directly the process of something happening or the process of making something. The drawback is that it requires the tools needed to demonstrate the making of something.

Experiment. The advantage of this method is that the child can do directly what he learns, for example doing something. Disadvantages are: (a) This method also tends to require experimental tools; and (b) In addition, the teacher must really pay attention to each child in carrying out their experiments.

Discussion. The advantages of this method are: (a) Children can exchange opinions with their friends about what they have learned; and (b) Encouraging children to socialize and develop their social aspects. The drawback is that sometimes children do not focus on what they are learning, often they are busy with themselves or outside of their duties.

Problem solving. The advantage of this method is that children are stimulated to have the ability to solve the problems they face. The drawback is that often children do not understand the steps so that the problem is not successfully solved.

Exercise. The advantage of the training method is that children can practice their abilities in completing the given task, usually the exercise is done repeatedly until the child masters the exercise material. The drawback is that sometimes children get bored, especially children who are talented and intelligent. Repeated exercises will make him bored and frustrated.

\section{Conclussion}

Early childhood is a child who has just been born until the age of 6 years. This age is a very decisive age in the formation of a child's character and personality. There are several methods that are usually applied to early childhood, including: playing, telling stories, singing, talking (dialogue with questions and answers), field trips, hands-on practice, role playing (social-drama), assignments and other methods that are considered capable of encouraging early childhood learning so as to achieve learning objectives. No one learning method is superior to the other. All methods are good as long as they are in accordance with the objectives to be achieved and the availability of children's learning facilities. Teachers are advised to use learning methods in accordance with the learning objectives to be achieved, as well as early childhood learning methods must adapt to the available facilities. Teachers should collaborate more with several learning methods so that the learning process is more interesting.

\section{References}

Anderson, L.M., Shinn, C., Fullilove, M.T., Scrimshaw, S.C., Fielding, J.E., Normand, J., and Carande-Kulis, V.G. (2003). The Effectiveness of Early Childhood Development Programs: A Systematic Review. American Journal of Preventive Medicine, 24(3 SUPPL.), 32-46.

Danby, S.J., Fleer, M., Davidson, C., and Hatzigianni, M. (2018). Digital Childhoods: Technologies and Children's Everyday Lives. Springer Nature: Singapore.

Directorate General of Out-of-school Education and Youth. (2002). Reference Learning Menu in Early Childhood Education (Generic Learning Menu). Depdiknas:Jakarta.

Ecker, E., and Skelly, A. (2010). Conducting a Winning Literature Search. Evidence-Based Spine-Care Journal, 1(1), 9-14.

Heckman, J.J. (2011). The Economics of Inequality: The Value of Early Childhood Education. American Educator, 35(1), 31-36.

Heckman, J.J. (2012). Invest in Early Childhood Development: Reduce Deficits, Strengthen the Economy. The Heckman Equation, 7(2012), 1-2.

Heirdsfield, A., Davis, J., Lennox, S., Walker, S., and Zhang, W. (2007). Online Learning Environments: What Early Childhood Teacher Education Students Say. Journal of Early Childhood Teacher Education, 28(2), 115-126.

Ministry of Education and Culture. (2007). Law No.20 of 2009 concerning the National Education System. Depdiknas:Jakarta.

Rahayu, W. and Munadi, M. (2019). Inculcation Religiosity in Preschoolers Local Content Curriculum. Jurnal Pendidikan Usia Dini, 13(2), 201-216.

Suwahono and Mawanti, D. (2019). Using Environmentally Friendly Media (Happy Body) in Early Childhood Science: Human Body Parts Lesson. Jurnal Pendidikan Usia Dini, 13(2), 281-295.

Triputra, D. R. (2020). Early Childhood Parenting in The Review of Islamic Religious Perspectives in Songgom Brebes. International Journal of Emerging Issues in Early Childhood Education, 2(1), 30-44. 